\title{
Retroperitoneal Tunneled Hemodialysis Catheter in Inferior Vena Cava: A Report of Three Cases
}

\author{
Inferior Vena Kavaya Retroperitoneal Tünelli Hemodiyaliz \\ Katateri: Üç Hastalık Olgu
}

\author{
(D) Okay Karaca ${ }^{1}$, (D) Ata Ecevit ${ }^{2}$, (D) Mehmet Kalender ${ }^{2}$, (D) Mehmet Taşar $^{3}$, (D) Turan Ege ${ }^{4}$ \\ ${ }^{1}$ Düzce University Faculty of Medicine, Cardiovascular Surgery, Düzce, Turkey \\ ${ }^{2}$ Konya Training and Research Hospital, Department of Cardiovascular Surgery, Konya, Turkey \\ ${ }^{3}$ Ankara University Faculty of Medical, Department of Cardiovascular Surgery, Ankara, Turkey \\ ${ }^{4}$ Trakya University Faculty of Medical, Department of Cardiovascular Surgery, Edirne, Turkey
}

Keywords

Chronic renal failure, emergency

hemodialysis, tunneled catheter

Anahtar Kelimeler

Kronik böbrek yetersizliği, acil hemodiyaliz, tünelli katater

Received/Geliş Tarihi : 19.08.2015

Accepted/Kabul Tarihi : 23.11.2015

doi:10.4274/meandros.galenos.2015.2560

Address for Correspondence/Yazışma Adresi: Okay Karaca MD,

Düzce University Faculty of Medicine, Cardiovascular Surgery, Düzce, Turkey

E-mail :drguven@gmail.com

ORCID ID: orcid.org/

(C) Meandros Medical and Dental Journal, Published by Galenos Publishing House.

This is article distributed under the terms of the

Creative Commons Attribution NonCommercial 4.0

International Licence (CC BY-NC 4.0).

\begin{abstract}
Finding an appropriate vascular access is difficult in long term hemodialysis patients for emergency hemodialysis. The aim of this study was to present tunneled hemodialysis catheter placement to inferior vena cava through retroperitoneal approach as an alternative method for patients who have emergency hemodialysis and no other choice. We placed tunneled hemodialysis catheter into inferior vena cava through retroperitoneal approach in three patients for emergency hemodialysis, two of them being female and one being male. The mean age of the patients was 51.3 years (min: 36 , max: 56 ) and mean dialysis time was for a period of 4.3 years (min: 2 , max: 6 ). In conclusion, placement of tunneled hemodialysis catheter into the inferior vena cava through retroperitoneal approach can be an alternative vascular access procedure for patients especially who have emergency hemodialysis and no other choice.
\end{abstract}

Öz

Uzun süre hemodiyalize giren hastalarda acil hemodiyaliz için yeterli damar giriş yolu bulmak zordur. Biz bu çalışmada acil hemodiyalize girecek olan başka bir seçeneği olmayan hastalarda alternatif bir metod olan retroperitoneal yaklaşımla inferior vena kava'ya tünelli hemodiyaliz katateri yerleştirilmesini göstermeyi amaçladık. İkisi kadın, bir tanasi erkek olan üç hastaya retroperitoneal yaklaşımla vena kava inferiora tünelli hemodiyaliz katateri yerleştirdik. Hastaların ortalama yaşı 51,3 (min: 36, maks: 56), ortalama diyaliz süresi 4,3 yıl (min: 2, maks: 6) idi. Sonuçta retroperitoneal yaklaşım ile vena kava inferiora tünelli hemodiyaliz katateri yerleştirilmesi özellikle acil hemodiyalize girecek ve başka bir seçeneği olmayan hastalarda alternatif bir damar giriş yolu olabilir.

\section{Introduction}

Finding an appropriate vascular access is difficult in long term hemodialysis patients for emergency hemodialysis. Tunneled hemodialysis catheter (THC) is a common and highly effective means of administering temporary venous access for dialysis for periods 
longer than three weeks (1). THC inserted through a central vein is a useful way for these patients. Commonly, catheterization of the right jugular vein is the first choice (2). Subclavian and femoral veins are also used. Long term hemodialysis requires multiple interventions to central veins, causing thrombosis. Particularly in this group of patients, alternative interventions for vascular access are required. The aim of this study was to present THC placement to inferior vena cava $(\mathrm{VCl})$ through retroperitoneal approach as an alternative method for emergency hemodialysis.

\section{Case Report}

\section{Patient Selection}

Patients who have bilateral occlusion of the jugular veins or subclavian veins, occlusion of the superior vena cava or chest wall abnormalities may be canalized for translumbar catheter placement (3). Patients who have morbid obesity and with stomas or open abdominal walls may be poor candidates for translumbar approach (4).

We placed THC into $\mathrm{VCl}$ through retroperitoneal approach in three patients for emergency hemodialysis, two of them being female and one being male. The mean age of the patients was 51.3 years (min: 36 , max: 56 ) and mean dialysis time was for a period of 4.3 years ( $\min : 2$, max: 6 ). The patients were operated between December 2011 and June 2013. Past medical history of the patients revealed peritonitis due to peritoneal dialysis. All patients had previous bilateral upper extremity radiocephalic and brachiobasilic arteriovenous fistulas which had failed. Following the failure of the fistulas, THC was placed in right and left jugular veins in all patients. Before the operation, venous Doppler ultrasonography was performed in all patients for both upper extremities and lower extremities. All patients had bilateral jugular and subclavian vein thrombosis. Two patients had venous thrombosis in one of the lower extremities.

\section{Operative Technique}

All patients were operated under general anesthesia with endotracheal intubation. Right retroperitoneal exposure was used to access $\mathrm{VCl}$. $\mathrm{VCl}$ was secured by silastic tapes proximally and distally. Systemic 5000 IU unfractionated heparin was applied intravenously. Purse string suture was placed on the $\mathrm{VCl}$. A $19 \mathrm{Fx} 32$ $\mathrm{cm}$ silicone double-lumen THC was inserted through previously prepared tunnel (Figure 1). After insertion of catheter, the purse string suture was tied. A closed suction drain was placed in the retroperitoneal space. The retroperitoneal space was closed in the routine manner. The subcutaneous tissues and skin were closed with an absorbable suture.

\section{Postoperative Care}

All patients were admitted to the postoperative intensive care unit. A single dose of prophylactic antibiotic (cefamezin) was administered. Patients received hemodialysis by the newly inserted catheter in the intensive care, when necessary. All patients were transferred to the surgical ward on the $2^{\text {nd }}$ postoperative day.

\section{Discussion}

To create an appropriate vascular access for patients undergoing long term hemodialysis is challenging. In this particular group of patients, alternative vascular access routes can be lifesaving. THCs, as described by Schwab et al. (5) for the first time, are used temporarily while patients have been waiting for fistula maturation, kidney transplantation or they are used for chronic vascular access (2). The dialysis outcomes quality initiative vascular access guideline recommends that no more than $10 \%$ of long-term hemodialysis access should be in the type of catheters (2). However, growing number of patients with long term hemodialysis require tunneled or non-tunneled central venous catheters due to increasing rates of thrombosis, vascular stenosis and infection (6-8).

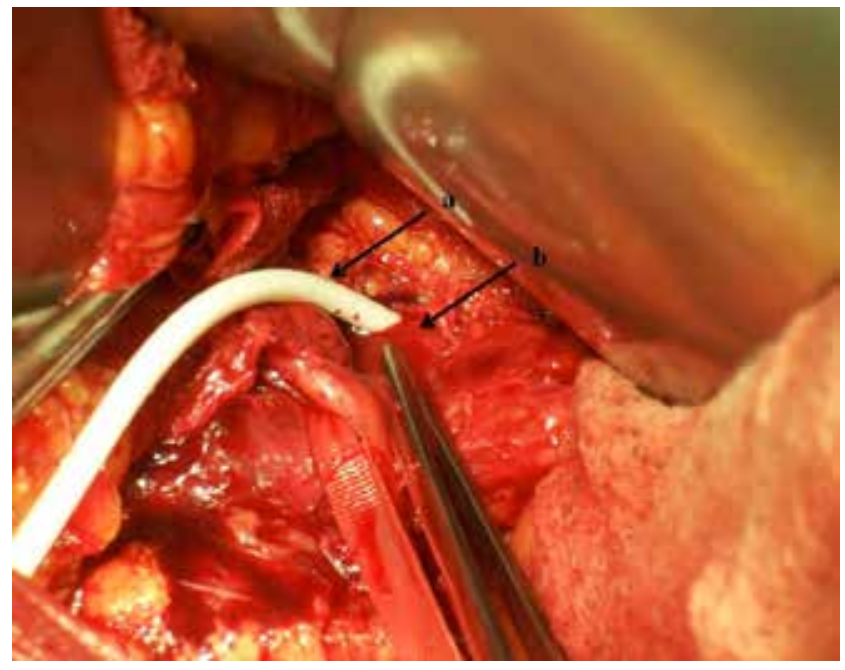

Figure 1. a: Tunneled catheter b: inferior vena cava 
In most patients, the right internal jugular vein is used more often than the left for central venous catheter. Access through the right internal jugular vein offers direct path to the right atrium, in contrast to the left internal jugular vein (9). The right internal jugular vein has the lowest risk of symptomatic central venous stenosis and thrombosis, and is technically easier to puncture using ultrasound guidance than any other central vein, with the exception of the femoral vein. Furthermore, thrombotic complications of the internal jugular vein catheters are usually asymptomatic because of the abundant network of collateral veins draining the head and neck (10).

Subclavian vein should generally be avoided for hemodialysis unless internal jugular access is unavailable. The subclavian vein has a number of unique disadvantages compared with the internal jugular vein, primarily because it provides venous drainage from the arm. Subclavian access is associated with high rates of stenosis and thrombosis (11). Subclavian vein puncture has the highest risk of pneumothorax and, if the puncture side is too far medial, catheter compression by the subclavius muscle-costoclavicular ligament complex may lead to fatigue and fracture, the so-called pinch-off syndrome $(12,13)$. The subclavian vein should not be used in any patient requiring hemodialysis unless the ipsilateral extremity is unsuitable for synthetic graft or fistula creation.

Femoral vein catheterization is more prone to mechanical and infectious complications when compared to jugular and subclavian veins (14).

Conventional access sites provide satisfactory routes for catheter placement; a variety of options have been developed when they are no longer available for access because of thrombosis from multiple prior catheterizations. Lau et al. (15) described innominate vein catheterization. Moreover, percutaneous translumbar $\mathrm{VCl}$, transsternal, transrenal, transhepatic venous access routes have been described (16-20). In one of our patients, multiple catheterizations, either permanent or temporary, were present in the past medical history together with thrombosis of bilateral jugular veins, subclavian and femoral vein. Numerous autologous arteriovenous fistulaes (AVFs) and synthetic AVFs in both upper extremities had ended with failure. In the other two patients, while Doppler ultrasonography did not reveal any thrombosis in only one of their lower extremities, catheterization failed. Catheterization through this region was present in the medical history. In order to meet the needs for hemodialysis in these three patients, THC was placed immediately into the $\mathrm{VCl}$ by the retroperitoneal approach.

The complications related to central venous catheterization may be classified under two groups: complications of device insertion and long-term complications. Complications of device insertion are pneumothorax, perforation, hemothorax and tamponade. Long term complications are infection, thrombosis, malfunction, compression, fracture and embolization (21). Our patients have been undergoing hemodialysis for a mean period of 10 months (min: 8, max: 12) without any complications.

In conclusion, placement of THC into the $\mathrm{VCl}$ through retroperitoneal approach can be an alternative vascular access procedure for patients especially who have emergency hemodialysis and no other choice. However, complications and catheter longevity should be taken into consideration.

\section{Ethics}

Informed Consent: We received consent from the patients.

Peer-review: Externally peer-reviewed.

\section{Authorship Contributions}

Surgical and Medical Practices: O.K., A.E., M.K., M.T., T..E., Concept: O.K., A.E., M.K., M.T., T..E., Design: O.K., A.E., M.K., M.T., T..E., Data Collection or Processing: O.K., A.E., M.K., M.T., T..E., Analysis or Interpretation: O.K., A.E., M.K., M.T., T..E., Literature Search: O.K., A.E., M.K., M.T., T..E., Writing: O.K., A.E., M.K., M.T., T..E.

Conflict of Interest: No conflict of interest was declared by the authors.

Financial Disclosure: The authors declared that this study received no financial support.

\section{References}

1. Foley RN, Collins AJ. End-stage renal disease in the United States: an update from the United States Renal Data System. J Am Soc Nephrol 2007; 18: 2644-8.

2. Vascular Access Work Group. Clinical practice guidelines for vascular access. Am J Kidney Dis 2006; 48(Suppl 1): S248-73.

3. JC Andrews. Translumbar Approach to the Inferior Vena Cava for Chronic Venous Access. Operative Techniques in General Surgery 2001; 3: 238-42. 
4. JC Andrews. Translumbar Approach to the Inferior Vena Cava for Chronic Venous Access. Operative Techniques in General Surgery 2001; 3: 238-42.

5. Schwab SJ, Buller GL, McCann RL, Bollinger RR, Stickel DL. Prospective evaluation of a Dacron cuffed hemodialysis catheter for prolonged use. Am J Kidney Dis 1988; 11: 166-9.

6. Liangos O, Gul A, Madias NE, Jaber BL. Long-term management of the tunneled venous catheter. Semin Dial 2006; 19: 158-64.

7. Ash SR. Fluid mechanics and clinical success of central venous catheters for dialysis--answers to simple but persisting problems. Semin Dial 2007; 20: 237-56.

8. Mickley V. Central vein obstruction in vascular access. Eur J Vasc Endovasc Surg 2006; 32: 439-44.

9. Gordon AC, Saliken JC, Johns D, Owen R, Gray RR. US-guided puncture of the internal jugular vein: complications and anatomic considerations. J Vasc Interv Radiol 1998; 9: 333-8.

10. Woda RP, Miner ME, McCandles C, et al. The effect of right internal jugular vein cannulation on intracranial pressure. J Neurosurg Anesthesiol 1996; 8: 286-92.

11. Chung HY, Beheshti MV. Principles of non-tunneled central venous access. Tech Vasc Interv Radiol 2011; 14: 186-91.

12. Krutchen AE, Bjarnason $H$, Stackhouse DJ, Nazarian GK, Magney JE, Hunter DW. The mechanisms of positional dysfunction of subclavian venous catheters. Radiology 1996; 200: 159-63.

13. Hinke DH, Zandt-Stastny DA, Goodman LR, Quebbeman EJ, Krzywda EA, Andris DA. Pinch-off syndrome: a complication of implantable subclavian venous access devices. Radiology 1990; 177: 353-6.
14. Merrer J, De Jonghe B, Golliot F, Lefrant JY, Raffy B, Barre E, et al. Complications of femoral and subclavian venous catheterization in critically ill patients: a randomized controlled trial. JAMA 2001; 286: 700-7.

15. Lau TN, Kinney TB. Direct US-guided puncture of the innominate veins for central venous access. J Vasc Interv Radiol 2001; 12: 641-5.

16. Lund GB, Trerotola SO, Scheel PJ Jr. Percutaneous translumbar inferior vena cava cannulation for hemodialysis. Am J Kidney Dis 1995; 25 : 732-7.

17. Murthy R, Arbabzadeh M, Lund G, Richard H 3rd, Levitin A, Stainken B. Percutaneous transrenal hemodialysis catheter insertion. J Vasc Interv Radiol 2002; 13: 1043-6.

18. Kurulay E, Karaca Y, Yoldaş S, Kaya T. Transsternal indwelling catheter insertion into superior vena cava. Turk J Thoracic and Cardio Surg 2013; 21: 242-4.

19. Stavropoulos SW, Pan JJ, Clark TW, Soulen MC, ShlanskyGoldberg RD, Itkin $\mathrm{M}$, et al. Percutaneous transhepatic venous access for hemodialysis. J Vasc Interv Radiol 2003; 14: 1187-90.

20. Butros SR, Walker TG, Salazar GM, Kalva SP, Oklu R, Wicky S, Ganguli $S$. Direct translumbar inferior vena cava ports for longterm central venous access in patients with cancer. J Vasc Interv Radiol 2014; 25: 556-60.

21. Whitman ED, Complications associated with the use of central venous access devices. Curr Probl Surg 1996; 33: 309-78. 